\title{
CELLS INVOLVED IN THE IMMUNE RESPONSE
}

\section{The Response of Normal and Immune Rabbit Bone Marrow and LyMPHOID TISSUE LyMPHOCYTES TO ANTIGENS IN Vitro*}

\author{
By SHARWAN K. SINGHAL, $\ddagger$ Ph.D., AND MAXWELL RICHTER, $\S$ M.D. \\ (From The Harry Webster Thorp Laboratory, Division of Immunochemistry \\ and Allergy, McGill University Clinic, Royal Victoria Hospital, \\ Montreal, Quebec, Canada)
}

(Received for publication 6 May 1968)

The role which the various cells comprising the lymphopoietic system play in the induction and maintenance of the humoral immune response is only now becoming more understood. A large body of experiments have implicated the cells belonging to the small lymphocyte-plasma blast-plasma cell series as those mediating the humoral immune response $(1-9,14,15,48-52)$. However, experiments have, by and large, been conducted mainly with spleen and lymph node $(1-9,14,15,48-52)$, and only occasionally with the thymus $(10,11,64,65)$. The other tissues comprising the lymphoid system-appendix, Peyer's patches, tonsil, sacculus rotundus (in the species where it constitutes an anatomically distinct organ), bone marrow and peripheral blood-have generally been bypassed by investigators concerned with the organ and cell site of antibody formation. Furthermore, the majority of investigations to date have been concerned primarily with the final cellular events occurring during the induction period and not with the initial sequence of cellular events occurring immediately following the administration of the antigen. Thus, the small lymphocyte or plasma cell may contain antibody or be capable of synthesizing antibody but there is no evidence to suggest that it is the same cell that has initially reacted with the antigen 8-12 days previously.

In a previous communication from this laboratory (20) it was demonstrated that bone marrow cells of normal rabbits are capable of responding upon initial exposure to an antigen in vitro with blastogenesis and radioactive thymidine incorporation. This response was not obtained with cells of the other lymphoid organs of the normal rabbit nor with bone marrow cells of previously immunized rabbits with respect to the immunizing antigen. Furthermore, initial experiments with marrow cells, following fractionation in a sucrose density gradient (21), implicated the bone marrow lymphocyte as the marrow cell capable of responding to antigen in vitro. We have further extended our ini-

* This work was supported by a grant from the Medical Research Council, Canada.

‡ Submitted in partial fulfillment of the Degree of Doctor of Philosophy, Department of Experimental Medicine, McGill University, Montreal, Quebec, Canada.

$\$$ Medical Research Associate, Medical Research Council, Canada. 
tial observations and the results of experiments presented below suggest that the bone marrow lymphocyte is the cell most concerned in the initiation of the primary immune response but that antibody formation, per se, and the induction and maintenance of the secondary response, is a function of the lymph node and splenic lymphocytes.

\section{Methods and Materials}

Animals and Antigens Used.-Only adult, 5 to $7 \mathrm{lb}$, outbred, white New Zealand rabbits were used in these experiments. They were injected with the antigen, in the appropriate concentration, intravenously and/or the foot pad or by the subcutaneous route according to the dictates of the particular experimental procedure. Unless otherwise stated the foot pad injection was made with the antigen emulsified in complete Freund's adjuvant (Difco Laboratories, Detroit, Mich.). The rabbits used for fragment culture experiments were injected twice intravenously (15 mg per injection) and in the foot pad (5 mg per injection) within a period of 7 days.

The antigens used were human serum albumin (HSA) (Hyland Laboratories, Los Angeles, Calif.), bovine serum albumin (BSA) (Pentex Incorporated, Kankakee, Ill.), rabbit serum albumin (RSA) (Pentex), dog serum albumin (DSA) (Pentex), horse serum albumin (HoSA) (Pentex), sheep serum albumin (SSA) (Pentex), cat serum albumin (CSA) (Pentex), ovalbumin (OA) (Pentex), bovine gamma-globulin (BGG) (Pentex), Keyhole Limpet hemocyanin (KLH) (Pacific Bio-Marine Supply Co., Venice Calif.), Salmonella O antigen (supplied by Dr. F. Daguillard, of this laboratory) and sheep erythrocytes (sheep-rbc).

Induction of Immunological Tolerance.-Neonatal rabbits were injected intraperitoneally at days 3 and 6 of age with $100 \mathrm{mg}$ of the antigen (HSA). They were left undisturbed with their uninjected littermates and were bled at $10 \mathrm{wk}$ of age. Several normal and "tolerant" rabbits of the litter were then injected intravenously with an immunogenic dose (10 $\mathrm{mg}$ ) of HSA while the remaining animals of the litter were sacrificed and the various lymphoid organs were excised. Cell suspensions and fragments were prepared from the various lymphoid organs and these preparations were tested for their immune reactivity by the fragment and cell culture techniques described below.

Fragment Culture Technique.-The organ was sliced with two scalpels to yield fragments as uniform as possible, approximately $1-1.5 \mathrm{~mm}^{3}$ in size. Eight fragments were distributed into each Leighton tube (Bellco Glass, Inc., Vineland, N. J.), onto a Gelfoam pad (Upjohn Co., Kalamazoo, Mich.) via a Pasteur pipette and the fragments were covered with a strip of Gelfilm (Upjohn Co.) (12). One ml of Medium 199 (Microbiological Associates, Inc., Bethesda, Md.), containing 20\% normal rabbit serum (NRS), 100 ug streptomycin and 100 units penicillin per $\mathrm{ml}$ (henceforth referred to as Med-PS-NRS) was added to each tube and the tubes were stoppered and placed in the horizontal position in a $37^{\circ} \mathrm{C}$ incubator. Where indicated, antigen was added to the tubes at the commencement of culture and allowed to incubate with the fragments for $2 \mathrm{hr}$. The culture fluid containing the antigen was then withdrawn, traces of antigen eliminated by three consecutive washes of the tissue fragments with Med-PS-NRS, and the tubes replenished with $1 \mathrm{ml}$ of culture medium. The medium was changed the next day and every 3rd to 4th day thereafter. The supernatants were tested for antibody activity by the tanned cell hemagglutination technique (13).

This technique of fragment culture has been found to be capable of maintaining antibody formation for periods up to $35-40$ days $(12,14,15)$.

Cell Culture Technique.-The technique of cell culture as used in this laboratory has been described in a previous communication (16). The rabbits were bled from the heart with a heparinized syringe and were then sacrificed by the intravenous administration of nembutol 
( $50 \mathrm{mg}$ per $\mathrm{kg}$ body $\mathrm{wt}$ ). The various organs were removed in rapid order and placed in MedPS-NRS, the entire procedure taking no longer than several minutes. The organs removed were the bone marrow (from the head and upper shaft of the tibia), popliteal lymph node, spleen, thymus, appendix, and sacculus rotundus. The blood was diluted with $6 \%$ dextran (mol wt 75,000) (Gentran, Don Baxter, Inc., Glendale, Calif.) in a ratio of 3:2 (blood:dextran). The mixture was introduced into sterile disposable plastic tubes (Falcon Plastics, Los Angeles, Calif.) which were placed at an angle of $60^{\circ}$ to the horizontal in an incubator at $37^{\circ} \mathrm{C}$ and allowed to sediment for 40-60 min. The leucocyte-rich plasma-dextran layer was carefully decanted, diluted 10-fold with Medium 199 and centrifuged at $800 \mathrm{~g}$ for $10 \mathrm{~min}$. The cells were resuspended in Medium 199 and washed once more. The organs other than the bone marrow were cut into small fragments and teased through a sterile wire mesh ( 50 mesh) by the application of slight pressure. The cells were collected into Med-PS-NRS. The bone marrow cell suspensions were prepared by flushing the bone marrow with several aliquots of normal rabbit serum into a sterile plastic tube. We have observed that the stability of the bone marrow cells is enhanced if NRS is used in place of Medium 199 containing heparin. The cell mass was gently shaken in the plastic tube and centrifuged at $500 \mathrm{~g}$ for $5 \mathrm{~min}$. The fatty upper layer was decanted and the cell button was resuspended in Med-PS-NRS. The cell suspensions of all the organs were diluted in Med-PS-NRS to contain $10^{6}$ lymphocytes per $\mathrm{ml}$. The various cell suspensions were then all treated in a similar fashion. $4 \mathrm{ml}$ of the suspension were placed into disposable sterile plastic tubes, $0.25 \mathrm{ml}$ of the antigen was added and the tubes were sealed and incubated at $37^{\circ} \mathrm{C}$. Approximately $24 \mathrm{hr}$ prior to the termination of culture, $2 \mu \mathrm{c}$ tritiated thymidine (SA $1.0 \mathrm{c}$ per $\mathrm{Mm}$ ) was added to each tube. At the end of culture the tubes were centrifuged at $1000 \mathrm{~g}$ for $10-15 \mathrm{~min}$, the supernatants were discarded and the cell buttons resuspended in $2 \mathrm{ml}$ of $5 \%$ trichloracetic acid. The tubes were centrifuged and washed once more in an identical fashion with trichloracetic acid. $1 / 2 \mathrm{ml}$ of Hyamine (Packard Instrument Co., Inc., Downers Grove, Ill.) was then added to each tube and the tubes were permitted to digest for $24 \mathrm{hr}$ at room temperature in the dark. The contents of the tubes were then transferred to scintillation counting vials using two washes of absolute ethanol $\left(0.6 \mathrm{ml}\right.$ total). The vials were than incubated at $70-75^{\circ} \mathrm{C}$ for $1 \mathrm{hr}$ and allowed to cool at room temperature, following which $15 \mathrm{ml}$ of scintillation solution (containing $400 \mathrm{gm}$ naphthalene, $28 \mathrm{gm}$ PPO, $1.2 \mathrm{gm}$ POPOP, made up to 3.8 liters with dioxane) were added to each vial. The vials were analyzed for their radioactive content in a Model 4000 Packard liquid scintillation counter. The results are expressed as counts per minute and as specific incorporation of tritiated thymidine which is the ratio of activity incorporated by the cells in the presence of antigen to that taken up in the absence of the antigen. (17).

The above procedure is essentially that described previously by Bain and Lowenstein

Fractionation of Normal Rabbit Bone Marrow.-A linear sucrose density gradient was prepared in a $15 \mathrm{ml}$ sterile polypropylene tube using the Buchler Gradient Mixer equipped with a vibration type stirrer assembly according to the procedure described by Osmond $(22,23)$. The proximal compartment was filled with a $15 \%$ sucrose solution in water containing $20 \%$ NRS. The distal compartment was filled with a 5\% sucrose solution made up in Hanks balanced salt solution or Medium 199 containing 20\% NRS. The rate of entry of fluid from the distal to the proximal compartment was equal to that dripping into the polypropylene tube from the proximal compartment, thus permitting the establishment of a linear density gradient.

The bone marrow cells were washed several times with Medium 199 and prepared as a suspension in $50 \%$ normal rabbit serum in a concentration of $200-300 \times 10^{6}$ cells per ml. $1 / 2$ to $1 \mathrm{ml}$ of this cell suspension was layered onto the surface of the linear sucrose gradient and the tube was centrifuged at $100 \mathrm{~g}$ for 3-5 min, following which the tube was punctured 
with a needle and the fractions collected in sterile plastic tubes. The cells were washed twice with Med-PS-NRS and resuspended in this medium to give a final cell concentration of $10^{6}$ cells per $\mathrm{ml}$. The response of the bone marrow cells in each fraction to antigen was determined using the cell culture technique as outlined above.

Radioautography.-For radioautographic analysis of the cell suspension following incubation with the antigen, the procedure followed was essentially that described by Kopriwa and Leblond (18). The cells were spread onto gelatin-coated glass slides which were then air dried. They were then coated in a photographic dark room with Kodak NTB-2 Liquid Nuclear Track Emulsion which was kept in a water bath at $37^{\circ} \mathrm{C}$ and allowed to stand for $30 \mathrm{~min}$ prior to use to permit any air bubbles to escape. The coated slides were maintained in a semi-vertical position in absolute darkness in specially constructed Plexiglass stands for 2-3 hr following which they were placed into black, light-tight plastic slide boxes containing a dessicant (Drierite) and stored at $4^{\circ} \mathrm{C}$ for 2-4 days. At the appropriate times the boxes were removed from the cold room, allowed to equilibrate to room temperature and the slides were developed with Kodak D-19 developer and fxed with Kodak fixer. They were then stained with Jenner stain and the labeled cells were examined for their morphological features under the microscope.

Fluorescent Antibody Technique.-Human serum albumin, bovine gamma globulin, and Keyhole limpet hemocyanin were conjugated to fluorescein isothiocyanate (FITC) (Dajac Laboratories, Philadelphia, Pa.), by the method of Clark and Shepard (19). The protein to be coupled was dissolved in $0.025 \mathrm{M}$ bicarbonate buffer, $\mathrm{pH} 9.0$, to a concentration of $10 \mathrm{mg}$ per $\mathrm{ml} .5 \mathrm{ml}$ of this solution was placed into a Visking cellophane sac (Visking Corporation, Chicago, Ill.) and dialyzed for $24 \mathrm{hr}$ against 10 volumes of a $10 \mathrm{mg} \%$ solution of FITC dissolved in the same buffer. The contents of the dialyzing sac were then dialyzed against phos-

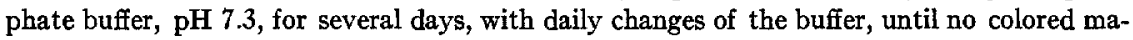
terial could be discerned emanating from the Visking sac. The contents of the dialysis sac were then frozen in $2 \mathrm{ml}$ aliquots and stored at $-10^{\circ} \mathrm{C}$ until used. The FITC-protein conjugate was not absorbed with guinea pig liver powder or any other organ prior to use.

Rabbit antisera to human serum albumin and bovine gamma globulin were precipitated at $40 \%$ ammonium sulfate, the precipitates were washed with ammonium sulfate, dissolved in water, dialyzed against distilled water for $24 \mathrm{hr}$ at $4^{\circ} \mathrm{C}$, and lyophilized. This gamma globulin fraction of the rabbit antiserum was then conjugated to FITC in the manner as described above. All preparations were mounted in buffered glycerol and studied immediately with a Reichert "Zetopan" microscope (Reichert Testers, Mineola, N. Y.) equipped with an Osram HBO 200 watt super pressure mercury lamp with an emission curve with two peaks at 365 and $435 \mathrm{~m} \mu$. An excitor filter and a Wratten blocking filter 1/GG9 (Eastman Kodak Co., Rochester, N. Y.) were interposed between the light source and the stage.

The Tanned Cell Hemagglutination Technique.-The tanned cell technique used here was essentially that as described by Boyden (13) with only minor modifications. All the antiserum samples were analyzed at the same time, in order to make a comparison between them valid. The titer of the antiserum is expressed as the maximum dilution capable of effecting agglutination of the sensitized cells.

\section{EXPERIMENTAL PROCEDURES AND RESULTS}

\section{Experiment I}

The In Vitro Blastogenic Response to Protein Antigens of Lymphoid Cell Suspensions Obtained From Previously Immunized Rabbits.-

Rabbits were immunized with HSA in the manner described above and sacrificed 5-7 months later when their circulating antibody titers had diminished to 10 to $20 \%$ of peak 
titers. The lymph nodes (popliteal), spleen, thymus, appendix, sacculus rotundus, and bone marrow were rapidly excised and placed in Med-PS-NRS. The cell suspensions were prepared as described above and they were incubated for varying intervals of time with the immunizing (HSA), cross-reacting (BSA), and unrelated ( $\mathrm{KLH}$ and BGG) antigens. Radioactive thymi-

\section{TABLE I}

The In Vitro Response to Protein Antigens of Lymph Node and Spleen Cells Obtained from a Rabbit Hyperimmunized to HSA 5 Months Prior to Sacrifice

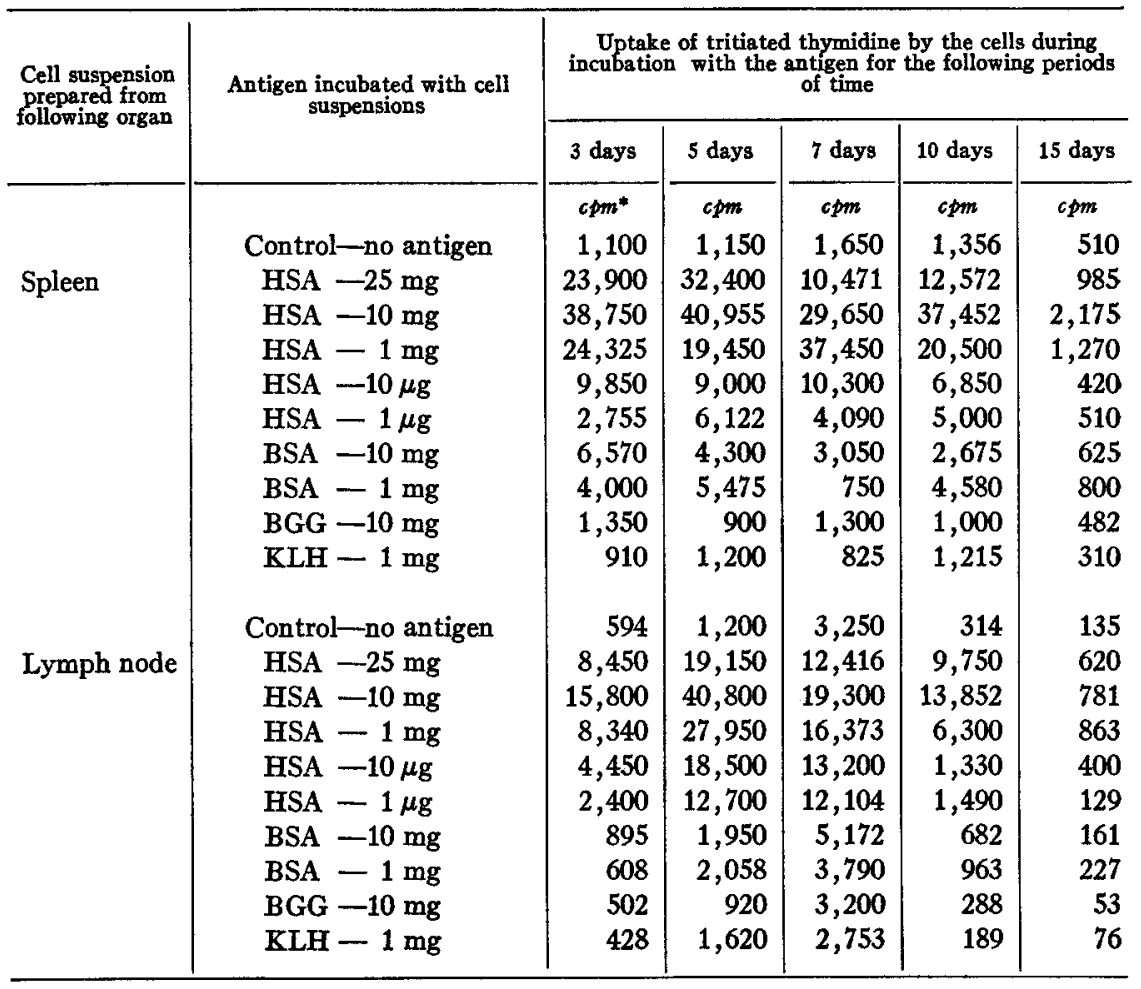

* Each value represents the mean of triplicate determinations.

dine was added $24 \mathrm{hr}$ prior to the termination of culture and the extent of radioactive thymidine incorporation by the cell suspension was determined, in the manner described above.

For radioautographic analysis, the cell suspensions at the termination of culture were smeared onto gelatin-coated glass slides which were then dried, coated with the photographic emulsion, stored at $4^{\circ} \mathrm{C}$, and developed and stained with Jenner stain.

As can be seen in Table I, the lymph node and spleen cell suspensions responded with marked blastogenesis and tritiated thymidine incorporation when incubated with HSA in vitro. The maximum response occurred between days 5 and 10 of culture. As little as $1 \mu \mathrm{g}$ HSA was capable of stimulating appreciable blastogenesis, although the optimal response was obtained with 
TABLE II

The In Vitro Response to Protein Antigens of Thymus, Appendix, and Sacculus Rotundus Cells Obtained from a Rabbit Hyperimmunized to HSA 5 Months Prior to Sacrifice

\begin{tabular}{|c|c|c|c|c|c|c|}
\hline \multirow{2}{*}{$\begin{array}{l}\text { Cell suspensions prepared } \\
\text { from following organ }\end{array}$} & \multirow{2}{*}{$\begin{array}{l}\text { Antigen incubated } \\
\text { with cell } \\
\text { suspensions }\end{array}$} & \multicolumn{5}{|c|}{$\begin{array}{l}\text { Uptake of tritiated thymidine by the cells during } \\
\text { incubation with antigens for the following } \\
\text { periods of time }\end{array}$} \\
\hline & & 3 days & 5 days & 7 days & 10 days & 15 days \\
\hline \multirow{10}{*}{ Thymus } & & $c p m^{*}$ & $\mathrm{cpm}$ & $c p m$ & $c p m$ & $c p m$ \\
\hline & Control & 803 & 180 & 131 & 90 & 38 \\
\hline & $\mathrm{HSA}-25 \mathrm{mg}$ & 650 & 75 & 98 & 110 & 25 \\
\hline & $\mathrm{HSA}-10 \mathrm{mg}$ & 900 & 137 & 100 & 55 & 68 \\
\hline & $\mathrm{HSA}-1 \mathrm{mg}$ & 575 & 105 & 70 & 22 & 51 \\
\hline & HSA -100 mg & 605 & 115 & 133 & 38 & 22 \\
\hline & $\mathrm{HSA}-10 \mu \mathrm{g}$ & 720 & 80 & 58 & 70 & 15 \\
\hline & BSA - $10 \mathrm{mg}$ & 829 & 69 & 49 & 50 & 30 \\
\hline & $\mathrm{KLH}-1 \mathrm{mg}$ & 375 & 125 & 80 & 30 & 48 \\
\hline & $\mathrm{BGG}-10 \mathrm{mg}$ & 400 & 200 & 105 & 75 & 10 \\
\hline \multirow[t]{5}{*}{ Appendix } & Control & 636 & 362 & 122 & $\mathrm{ND} \ddagger$ & ND \\
\hline & $\mathrm{HSA}-25 \mathrm{mg}$ & 657 & 326 & 121 & ND & ND \\
\hline & HSA - $10 \mathrm{mg}$ & 507 & 148 & 72 & ND & ND \\
\hline & $\mathrm{HSA}-1 \mathrm{mg}$ & 343 & 152 & 76 & $\mathrm{ND}$ & $\mathrm{ND}$ \\
\hline & $\mathrm{KLH}-1 \mathrm{mg}$ & 610 & 217 & 71 & ND & $\mathrm{ND}$ \\
\hline \multirow[t]{4}{*}{ Sacculus rotundus } & Control & 235 & 142 & 108 & ND & ND \\
\hline & $\mathrm{HSA}-25 \mathrm{mg}$ & 231 & 181 & 82 & ND & ND \\
\hline & $\mathrm{HSA}-10 \mathrm{mg}$ & 178 & 160 & 48 & ND & ND \\
\hline & $\mathrm{HSA}-1 \mathrm{mg}$ & 129 & 130 & 72 & ND & $\mathrm{ND}$ \\
\hline
\end{tabular}

* Each value represents the mean of triplicate determinations.

$\ddagger N D$, not done.

TABLE III

The In Vitro Response to Antigens of Bone Marrow Cells of a Rabbit Hyperimmunized to HSA 5 Months Prior to Sacrifice

\begin{tabular}{l|c|c|c|c|c}
\hline \multirow{2}{*}{$\begin{array}{c}\text { Antigen incubated with } \\
\text { cell suspensions }\end{array}$} & \multicolumn{3}{|c}{$\begin{array}{c}\text { Tritium uptake by the bone marrow cells incubated in vitro } \\
\text { with antigen for the following periods of time }\end{array}$} \\
\cline { 2 - 6 } & 3 days & 5 days & 7 days & 10 days & 15 days \\
\hline & $c p m^{*}$ & $c p m$ & $c p m$ & $c p m$ & $c p m$ \\
Control & 36,005 & 4,683 & 3,465 & 1,296 & 444 \\
HSA -25 mg & 33,500 & 3,900 & 2,300 & 1,350 & 350 \\
HSA -10 mg & 37,685 & 3,808 & 2,975 & 1,049 & 520 \\
HSA - 1 mg & 47,440 & 5,182 & 3,204 & 1,050 & 580 \\
KLH - 1 mg & 50,200 & 15,020 & 10,700 & 3,600 & 1,200 \\
BGG -25 mg & 44,100 & 10,800 & 8,942 & 2,900 & 760 \\
\hline
\end{tabular}

* Each value represents the mean of triplicate determinations. 
$10 \mathrm{mg}$. A much lower response was obtained with BSA, a cross-reacting antigen, and no response was obtained with $\mathrm{KLH}$ and BGG.

Thymus, appendix, and sacculus rotundus cell suspensions failed to respond to any of the antigens with which they were incubated in vitro (Table II).

TABLE IV

Relationship between Antibody Formation by Lymph Node Fragments from Previously Immunized Rabbits and the Extent of Radioactive Thymidine Incorporation by Cell Suspensions Obtained from the Same Lymph Node upon Incubation with the Antigen (HSA) In Vitro

\begin{tabular}{|c|c|c|c|c|c|c|c|c|}
\hline & \multicolumn{8}{|c|}{ Cells and supernatants analyzed after incubation for } \\
\hline & 3 days & 4 days & 5 days & 7 days & 10 days & 14 days & 17 days & $\begin{array}{r}20 \\
\text { days }\end{array}$ \\
\hline \multicolumn{9}{|l|}{$\begin{array}{l}\text { Antibody titers* of } \\
\text { fragments super- } \\
\text { natants of } \\
\text { Rabbit I }\end{array}$} \\
\hline Control & 0 & ND§ & ND & 40 & 160 & 320 & 320 & 160 \\
\hline $\begin{array}{l}\text { Plus Antigen } \\
\text { Rabbit II }\end{array}$ & 0 & ND & ND & 320 & 20,000 & 20,000 & 5,120 & 2,560 \\
\hline Control & 0 & ND & ND & 40 & 80 & 20 & 0 & 0 \\
\hline Plus Antigen & 0 & ND & ND & 640 & 2,560 & 320 & 320 & 80 \\
\hline $\begin{array}{l}\text { Uptake of tritiated } \\
\text { thymidine } \ddagger \text { by } \\
\text { lymph node cells } \\
\text { of } \\
\text { Rabbit I }\end{array}$ & & & & & & & & \\
\hline Control & 527 & 2,500 & 3,660 & 2,365 & 1,630 & 253 & 175 & ND \\
\hline Plus Antigen & 7,770 & 36,735 & 62,575 & 48,560 & 23,070 & 5,646 & 1,380 & ND \\
\hline Rabbit II & & & & & & & & \\
\hline Control & 335 & 895 & 1,600 & 1,700 & 1,100 & 600 & 52 & ND \\
\hline Plus Antigen & 3,880 & 42,975 & 39,975 & 23,535 & 8,845 & 3,200 & 430 & ND \\
\hline
\end{tabular}

* The titer is expressed as the maximum dilution capable of effecting agglutination of the sensitized red cells. Each value represents the mean of duplicate determinations: Titers less than 10 are considered to be negative.

$\ddagger$ Expressed as counts per minute (per $4 \times 10^{6}$ cells incubated in $4 \mathrm{ml}$ of medium). Each value represents the mean of triplicate determinations.

$\$ \mathrm{ND}$, not done.

As can be seen in Table III, the bone marrow cells responded minimally, if at all, to HSA, whereas these cells responded markedly to BGG and KLH, especially by days 5 to 7 of culture.

The results of the radioautographic analyses of the incubated lymph node cells are presented in Fig. 1. The majority of the labeled cells following incubation with the specific antigen were distinguished as blasts and plasma-like cells. There appeared to be a direct correlation between the uptake of 
tritiated thymidine by the cell suspensions as determined by scintillation counting and the number of labeled cells seen in radioautographs. Control specimens incubated in the absence of the antigen contained very few labeled cells, the majority of the cells being small lymphocytes. The radioautographs of spleen cells incubated with the specific antigen were similar to those of the

TABLE V

The Incorporation of Tritiated Thymidine by Normal Rabbit Bone Marrow Cells Following Incubation with Various Protein Antigens for Varying Periods of Time

\begin{tabular}{|c|c|c|c|c|c|c|c|}
\hline \multirow{2}{*}{$\begin{array}{l}\text { Antigen incubated } \\
\text { with cell } \\
\text { suspensions }\end{array}$} & \multicolumn{7}{|c|}{$\begin{array}{l}\text { Uptake of tritiated thymidine by the cells following incubation for the } \\
\text { following periods of time }\end{array}$} \\
\hline & 1 day & 2 days & 3 days & 5 days & 7 days & 10 days & 15 days \\
\hline$m g$ & $c p m^{*}$ & $\mathrm{cpm}$ & $\mathrm{cpm}$ & $c p m$ & cpm & $c p m$ & $\mathrm{cpm}$ \\
\hline Control & 194,192 & 126,602 & 32,905 & 2,296 & 1,349 & 267 & 155 \\
\hline RSA -50.0 & 78,020 & 46,778 & 5,946 & 423 & 158 & 75 & 57 \\
\hline RSA -25.0 & 105,263 & 91,342 & 30,204 & 1,505 & 1,039 & 113 & 114 \\
\hline RSA -10.0 & 142,886 & 97,087 & 23,872 & 1,883 & 1,395 & 143 & 107 \\
\hline $\mathrm{RSA}-1.0$ & 172,413 & 120,879 & 30,060 & 1,945 & 1,270 & 246 & 130 \\
\hline $\mathrm{HSA}-50.0$ & 142,881 & 143,892 & 92,982 & 5,715 & 2,134 & 1,095 & 217 \\
\hline $\mathrm{HSA}-25.0$ & 163,912 & 156,288 & 88,061 & 7,482 & 3,818 & 1,575 & 1,722 \\
\hline $\mathrm{HSA}-10.0$ & 173,934 & 141,221 & 65,040 & 5,653 & 2,083 & 847 & 345 \\
\hline $\mathrm{HSA}-1.0$ & 145,833 & 129,546 & 31,653 & 2,731 & 1,418 & 495 & 301 \\
\hline $\mathrm{BSA}-50.0$ & 124,549 & 135,216 & 64,621 & 19,013 & 11,500 & 2,584 & 195 \\
\hline BSA -25.0 & 163,978 & 140,845 & 97,563 & 19,380 & 4,091 & 1,814 & 350 \\
\hline$B S A-10.0$ & 179,520 & 140,738 & 82,722 & 10,154 & 3,708 & 1,677 & 745 \\
\hline$B S A-1.0$ & 180,312 & 128,221 & 44,248 & 2,333 & 1,135 & 663 & 320 \\
\hline KIH -2.0 & 178,380 & 128,500 & 80,875 & 7,500 & 2,900 & 875 & 510 \\
\hline KLH - 1.0 & 180,300 & 160,210 & 102,310 & 10,642 & 4,364 & 1,420 & 642 \\
\hline $\mathrm{KLH}-0.5$ & 160,000 & 148,200 & 100,892 & 6,650 & 4,000 & 1,100 & 600 \\
\hline
\end{tabular}

* Each value represents the mean of triplicate determinations.

lymph node cells. Radioautographs of thymus, appendix, and sacculus rotundus cells did not disclose any increase of labeling when compared with control cultures incubated in the absence of the antigen. Radioautographs of the bone marrow cell suspensions incubated with the specific immunizing antigen disclosed few labeled cells, with the majority of the cells classified as immature myeloid and erythroid cells. On the other hand, radioautographs of bone marrow cells obtained from the HSA-immunized rabbits and incubated with KLH or BGG contained many labeled blast cells (Fig. 2).

The entire experiment was repeated 5 times with essentially similar results. 


\section{Experiment II}

Relationship Between the Secondary Immune Response by Lymph Node Fragments From Previously Immunized Rabbits and the Blastogenic Response by Cell Suspensions Obtained From the Lymph Nodes of the Same Rabbits.-

Rabbits were immunized with HSA and sacrificed 5-7 months later. Fragment and cell culture studies were carried out with the popliteal lymph nodes. The supernatants of the fragment cultures were analyzed for their antibody content by the tanned cell hemagglutination technique and the cell suspensions were analyzed for their incorporation of tritiated thymidine.

As can be seen in Table IV, the lymph node fragments responded with marked antibody formation following incubation with the antigen $(1 \mathrm{mg}$ HSA) for $2 \mathrm{hr}$. The peak antibody titer was attained by days 10 to 14 and antibody could still be detected by day 20 of culture.

The lymph node cell suspensions responded with marked blastogenesis and incorporation of tritiated thymidine upon incubation with HSA $(1 \mathrm{mg})$ for the entire period of culture. The response was already initiated by day 3 of culture, attained maximum levels by days $7-10$, and could still be detected by day 20 when compared with control tubes. A correlation was found to exist between the extent of antibody formation by the fragments and the incorporation of tritiated thymidine by the cell suspensions obtained from the lymph nodes of the same rabbit (Table IV).

\section{Experiment III}

The Incorporation of Tritiated Thymidine by Normal Rabbit Lymphoid Cell Suspensions Incubated With Various Protein Antigens.-

The lymph node (popliteal), spleen, thymus, appendix, sacculus rotundus, and bone marrow were obtained from normal, unimmunized rabbits. The cell suspensions were prepared and incubated for varying intervals of time with various concentrations of several protein antigens and the cell cultures were analyzed for their reactivity by their incorporation of tritiated thymidine.

As can be seen in Table V, the normal bone marrow cell suspensions responded with marked blastogenesis and incorporation of tritiated thymidine upon incubation with various concentrations of several protein antigens-HSA, BSA and KLH. The response was maximal at day 5 and could still be obtained by day 15 when compared to control cultures. As anticipated, the bone marrow cells failed to respond when incubated with RSA. Table VI shows the marked incorporation of tritiated thymidine obtained with normal rabbit bone marrow cells incubated with various concentrations of various other antigens for 3 days in vitro.

None of the cell suspensions prepared from the other lymphoid organs of the normal rabbits responded upon incubation with antigen in vitro. 
The number of bone marrow cells normally cultured per tube $\left(4 \times 10^{6}\right)$ were found to respond optimally upon exposure to antigen for 3-5 days. Doubling the number of cells per tube resulted in only a slight increase in tritiated thymidine uptake, whereas halving the number of cells per tube $\left(2 \times 10^{6}\right)$ resulted in a marked diminution in thymidine uptake.

\section{Experiment IV}

The In Vitro Response to Protein Antigens of Bone Marrow Cells Obtained From Rabbits at Varying Times Following the Administration of Antigen.-

Rabbits were given either a single intravenous or subcutaneous injection of the antigen (HSA, BGG, or KLH) in various concentrations. The subcutaneous injection consisted of

\section{TABLE VI}

The Incorporation of Tritiated Thymidine by Normal Rabbii Bone Marrow Cells Following Incubation with Various Antigens for 3 Days

\begin{tabular}{|c|c|}
\hline Antigen incubated with cell suspensions & $\begin{array}{l}\text { Uptake of tritiated thymidine by } \\
\text { the cells following incubation } \\
\text { for } 3 \text { days }\end{array}$ \\
\hline & $c p m^{*}$ \\
\hline Control-no antigen & 25,800 \\
\hline DSA $-10.00 \mathrm{mg}$ & 45,700 \\
\hline $1.00 \mathrm{mg}$ & 64,450 \\
\hline $\mathrm{HoSA}-10.00 \mathrm{mg}$ & 35,270 \\
\hline $\mathrm{SSA}-10.00 \mathrm{mg}$ & 26,212 \\
\hline $\mathrm{CSA}-10.00 \mathrm{mg}$ & 42,700 \\
\hline $1.00 \mathrm{mg}$ & 57,230 \\
\hline $\mathrm{OA} \quad-10.00 \mathrm{mg}$ & 40,402 \\
\hline HGG $-25.00 \mathrm{mg}$ & 45,000 \\
\hline $10.00 \mathrm{mg}$ & 39,403 \\
\hline $1.00 \mathrm{mg}$ & 35,609 \\
\hline BGG $-25.00 \mathrm{mg}$ & 50,200 \\
\hline $10.00 \mathrm{mg}$ & 34,852 \\
\hline $1.00 \mathrm{mg}$ & 26,208 \\
\hline Salmonella $\mathrm{O}-10.00 \mu \mathrm{g}$ & 39,345 \\
\hline $1.00 \mu \mathrm{g}$ & 57,144 \\
\hline $0.10 \mu \mathrm{g}$ & 48,875 \\
\hline $0.01 \mu \mathrm{g}$ & 30,503 \\
\hline Sheep-rbc $\quad-0.20 \mathrm{ml}$ & 45,555 \\
\hline$(10 \%)$ & 42,379 \\
\hline
\end{tabular}

* Each value represents the mean of triplicate determinations. 
either the antigen in saline or emulsified in Freund's complete adjuvant. The animals were sacrificed at various intervals of time and their bone marrow cells were prepared and cultured in the presence of the immunizing and other protein antigens. Their response was measured by the incorporation of tritiated thymidine.

The effect of the intravenous administration of HSA on the in vitro response of bone marrow cells to various antigens is presented in Table VII. The bone

TABLE VII

The In Vitro Response to Protein Antigens of Bone Marrow Cells Obtained from Rabbits at Varying Times Following the Intravenous Administration of $H S A$

\begin{tabular}{c|c|c|c|c|c|c|c|c}
\hline $\begin{array}{c}\text { Amount of } \\
\text { antigen } \\
\text { injected } \\
\text { (USA) }\end{array}$ & $\begin{array}{c}\text { Time of } \\
\text { sacrifice } \\
\text { following } \\
\text { administra- } \\
\text { tion of the } \\
\text { antigen }\end{array}$ & \multicolumn{2}{|c|}{ Uptake of tritiated thymidine by the bone marrow cells during incubation with } \\
the following antigens for 5 days
\end{tabular}

* Each value represents the mean of triplicate determinations.

marrow cells responded to all the antigens when excised and cultured 15 min following the intravenous administration of HSA. However, the bone marrow cells obtained from the rabbits $24 \mathrm{hr}$ after they had been injected intravenously with 5,25 , or $100 \mathrm{mg}$ HSA did not respond to HSA, but did to the other antigens. This inability of the bone marrow cells to respond to the specific antigen has been found to last at least 5-7 months following its administration. The reactivity to HSA of the bone marrow cells obtained from rabbits injected with $1 \mathrm{mg}$ HSA was still present by day 10, but no longer detected by day 15 . The reactivity of these in vivo "HSA-primed" bone marrow cells to other 
antigens was comparable at all times to that obtained with cells of normal, uninjected rabbits.

The effect of the subcutaneous administration of HSA alone or in Freund's adjuvant on the in vitro response of the bone marrow cells to various antigens was similar to the results obtained above. In both cases, the bone marrow cells responded to HSA when cultured 1 or $24 \mathrm{hr}$ following the administration of 5 or $25 \mathrm{mg}$ HSA, but this response was absent by day 10 . The cells obtained from rabbits injected with $1 \mathrm{mg}$ HSA responded to HSA in vitro on

TABLE VIII

The In Vitro Response to Protein Antigens of Bone Marrow Cells Obtained from Rabbits at Varying Times Following the Intravenous Administration of BGG

\begin{tabular}{|c|c|c|c|c|c|c|c|c|}
\hline \multirow{2}{*}{$\begin{array}{c}\text { Amount } \\
\text { of anti- } \\
\text { gen } \\
\text { injected } \\
\text { (BGG) }\end{array}$} & \multirow{2}{*}{$\begin{array}{l}\text { Time of } \\
\text { sacrifice } \\
\text { fol owing } \\
\text { administra- } \\
\text { tion of the } \\
\text { antigen }\end{array}$} & \multicolumn{7}{|c|}{$\begin{array}{c}\text { Uptake of tritiated thymidine by the bone marrow cells during incubation } \\
\text { with the following antigens for } 3 \text { days }\end{array}$} \\
\hline & & Control & $\underset{(25 \mathrm{mg})}{\text { BGG }}$ & $\begin{array}{c}\text { BGG } \\
(10 \mathrm{mg})\end{array}$ & $\underset{(1 \mathrm{mg})}{\mathrm{BGG}}$ & $\underset{(1 \mathrm{mg})}{\mathrm{KLH}}$ & $\underset{(25 \mathrm{mg})}{\text { HSA }}$ & $\underset{(25 \mathrm{mg})}{\mathrm{BSA}}$ \\
\hline$m g$ & & $c p m^{*}$ & $\mathrm{cpm}$ & $c p m$ & $c p m$ & $c p m$ & $c p m$ & $c p m$ \\
\hline 25 & $15 \mathrm{~min}$ & 36,005 & 83,800 & 66,300 & 29,995 & 108,682 & 86,105 & 97,449 \\
\hline 25 & $4 \mathrm{hr}$ & 42,942 & 54,300 & 46,850 & 51,145 & 100,866 & 128,100 & 138,601 \\
\hline 25 & $24 \mathrm{hr}$ & 43,465 & 32,040 & 30,764 & 27,378 & 148,040 & 129,515 & 115,995 \\
\hline 25 & 2 days & 44,352 & 18,300 & 32,608 & 36,709 & 129,287 & 72,256 & 68,876 \\
\hline 25 & 5 days & 46,260 & 39,576 & 33,800 & 41,596 & 111,174 & 103,290 & 69,600 \\
\hline 25 & 10 days & 28,680 & 20,595 & 27,630 & 13,957 & 148,306 & 64,490 & 78,259 \\
\hline
\end{tabular}

* Each value represents the mean of triplicate determinations.

day 10 , but not by day 15 . The reactivity of the bone marrow cells to other antigens was not affected by the subcutaneous administration of HSA.

The effect of the intravenous administration of BGG or KLH on the in vitro response of the bone marrow cells is presented in Tables VIII and IX. The results observed in these experiments were essentially the same as those described above, in that bone marrow cells obtained from rabbits injected with BGG and KLH lost their capacity to respond in vitro when exposed to $\mathrm{BGG}$ and $\mathrm{KLH}$, respectively. However, the response of the bone marrow cells to the nonimmunizing antigens was not affected.

Experiment V

The In Vitro Response To Protein Antigens of Bone Marrow, Lymph Node and Spleen Cells Obtained From Rabbits Made Tolerant To BSA.-

Neonatal rabbits were made tolerant to HSA in the manner described above. At 10 wk of age, cell suspensions of the bone marrow, lymph node, and spleen of "tolerant" and normal littermates were prepared and cultured in the presence of HSA and other antigens for 3 days. The cell responses obtained were measured by the determination of the tritiated thymidine 
incorporated by the cell suspension. Cultures were also set up with the lymph node fragments to study their capacity to synthesize antibody in vitro.

The lymph node fragments failed to synthesize and/or release sufficient antibody which could be detected by the tanned cell hemagglutination technique.

None of the rabbits which had been injected with the antigen (HSA) on days 3 and 6 of age produced any antibody upon reinjection with the antigen at $10 \mathrm{wk}$ of age. On the other hand, littermates which had not been exposed

TABLE IX

The In Vitro Response to Protein Antigens of Bone Marrow Cells Obtained from Rabbits at Varying Times Following the Intravenous Administration of $K L H$

\begin{tabular}{|c|c|c|c|c|c|c|c|}
\hline \multirow{2}{*}{$\begin{array}{c}\text { Amount of } \\
\text { Antigen } \\
\text { Injected } \\
(\mathrm{KLH})\end{array}$} & \multirow{2}{*}{$\begin{array}{c}\text { Time of } \\
\text { sacrifice } \\
\text { following } \\
\text { adminis- } \\
\text { tration of } \\
\text { the antigen }\end{array}$} & \multicolumn{6}{|c|}{$\begin{array}{c}\text { Uptake of tritiated thymidine by the bone marrow cells during incubation with } \\
\text { the following antigens for } 5 \text { days }\end{array}$} \\
\hline & & Control & $\underset{(2 \mathrm{mg})}{\mathrm{KLH}}$ & $\begin{array}{l}\text { KLH } \\
(1 \mathrm{mg})\end{array}$ & $\underset{(25 \mathrm{mg})}{\mathrm{HSA}}$ & $\underset{(25 \mathrm{mgg})}{\text { BSA }}$ & $\begin{array}{l}\text { BGG } \\
(25 \mathrm{mg})\end{array}$ \\
\hline ms & $h r$ & $\mathrm{cpm}^{*}$ & $c p m$ & $c p m$ & $c p m$ & $c p m$ & $c p m$ \\
\hline 10 & 1 & 9,325 & 20,708 & 23,200 & 24,607 & 28,529 & 14,000 \\
\hline 10 & 4 & 11,250 & 7,500 & 9,720 & 30,746 & 39,000 & 15,900 \\
\hline 10 & 24 & 8,500 & 6,775 & 8,320 & 19,860 & 33,258 & 13,590 \\
\hline 2 & 1 & 6,528 & 18,256 & 21,900 & 17,308 & 22,878 & 10,500 \\
\hline 2 & 4 & 5,650 & 4,350 & 4,520 & 40,240 & 14,848 & 9,875 \\
\hline 2 & 24 & 6,500 & 4,275 & 5,600 & 15,775 & 18,229 & 9,408 \\
\hline
\end{tabular}

* Each value represents the mean of triplicate determinations.

to the antigen in the immediate neonatal period responded with antibody formation (hemagglutination titers of 640-5120) following administration of the antigen at $10 \mathrm{wk}$ of age. One may therefore assume that the regime of antigen administration in the neonatal period did indeed induce a state of immunological tolerance.

The lymph node and spleen cell suspensions of the tolerant rabbits did not respond to the immunizing antigen. The bone marrow cells also failed to respond to HSA, the tolerance-inducing antigen, but they responded markedly to BGG and KLH (Table $\mathrm{X}$ ). The bone marrow cells of normal nontolerant littermates responded to all the antigens.

\section{Experiment VI}

Detection of Specific Antibody Within Bone Marrow Lymphoid Cells by the Fluorescent Antibody Technique.-

Bone marrow cells were obtained from normal rabbits and cell cultures set up as described previously. The antigen (HSA), in a concentration of $25 \mathrm{mg}$ per tube, was incubated with the 
cells for the first 3 days of the 5 day culture period. The tubes were then spun at $600 \mathrm{~g}$ for 8-10 min, the supernatants were decanted and the cells resuspended in medium 199 and centrifuged a second time. The cells were washed two more times, resuspended in a small volume of medium $199(0.2 \mathrm{ml})$, and smeared onto precleaned glass slides which were then air dried, fixed with absolute ethanol at $4^{\circ} \mathrm{C}$ for $2-3 \mathrm{~min}$, and stored in Coplin jars at $4^{\circ} \mathrm{C}$. The fluorescent antibody staining technique consisted of overlaying the fixed slides with $0.3 \mathrm{ml}$ of each

TABLE X

The In Vitro Response to Protein Antigens of Bone Marrow, Lymph Node, and Spleen Cells Obtained From Rabbits Made Tolerant to HSA

\begin{tabular}{|c|c|c|c|c|}
\hline \multirow{2}{*}{$\begin{array}{l}\text { Cell suspensions prepared } \\
\text { from following organs }\end{array}$} & \multirow{2}{*}{$\begin{array}{l}\text { Antigen incubated with } \\
\text { cell suspensions }\end{array}$} & \multicolumn{3}{|c|}{$\begin{array}{l}\text { Uptake of tritiated thymidine by the bone marrow cells } \\
\text { during incubation with antigens for } 3 \text { days }\end{array}$} \\
\hline & & $\begin{array}{l}\text { A. Tolerant } \\
\text { Rabbit }\end{array}$ & $\begin{array}{l}\text { B. Tolerant } \\
\text { Rabbit }\end{array}$ & $\underset{\text { Rabbit }}{\text { C. Normal }}$ \\
\hline & $m g$ & $c p m^{*}$ & $c p m$ & $c p m$ \\
\hline Bone marrow & Control & 58,415 & 52,000 & 43,910 \\
\hline Bone marrow & HSA 50 & 39,873 & 51,200 & 89,185 \\
\hline Bone marrow & HSA 25 & 50,825 & 46,028 & 120,748 \\
\hline Bone marrow & HSA 10 & 55,275 & 49,440 & 101,455 \\
\hline Bone marrow & HSA 1 & 57,321 & 42,015 & 41,270 \\
\hline Bone marrow & $\mathrm{KLH} \quad 1$ & 104,830 & 120,575 & 129,900 \\
\hline Bone marrow & BSA 25 & 70,080 & 59,175 & 87,300 \\
\hline Bone marrow & BSA 10 & 70,000 & 53,475 & 80,590 \\
\hline Bone marrow & BGG 25 & 80,840 & 89,948 & 58,780 \\
\hline Lymph node & Control & 2,148 & 1,366 & 657 \\
\hline Lymph node & HSA 25 & 1,357 & 1,052 & 540 \\
\hline Lymph node & $\mathrm{HSA} 10$ & 1,704 & 1,035 & 335 \\
\hline Lymph node & $\mathrm{HSA} 1$ & 1,311 & 1,311 & 515 \\
\hline Spleen & Control & 1,755 & 1,235 & 1,198 \\
\hline Spleen & HSA 25 & 1,481 & 1,140 & 1,048 \\
\hline Spleen & HSA 10 & 1,359 & 849 & 1,125 \\
\hline Spleen & HSA 1 & 1,146 & 1,215 & 942 \\
\hline
\end{tabular}

* Each value represents the mean of triplicate determinations.

of the fluorescein-isothiocyanate (FITC) conjugated antigens (HSA-FITC, BGG-FITC, and KLH-FITC) for $30 \mathrm{~min}$. For the "sandwich" technique, the slides were first incubated with HSA or BGG or KLH (each made up to $50 \mathrm{mg}$ per $\mathrm{ml}$ ) for $30 \mathrm{~min}$ followed by a $30 \mathrm{~min}$ wash with buffered saline (pH 7.2) and incubation with anti-HSA-FITC or anti-BGG-FITC. The fluorescein conjugate was left undisturbed on the slide for $\mathbf{3 0 ~ m i n ~ a f t e r ~ w h i c h ~ t h e ~ s l i d e s ~ w e r e ~}$ washed with buffered saline, coverslipped and examined under the fuorescence microscope.

As can be seen in Table XI, fluorescence was only observed when the HSAincubated bone marrow cells were stained with HSA-FITC. BGG-FITC and KLH-FITC produced no fluorescence. Furthermore, anti-HSA-FITC and anti-BGG-FITC were also unable to stain the cells on the slide. When the sandwich technique was employed, only the HSA and anti-HSA-FITC combination produced fluorescence, which was quite marked (Fig. 3). 


\section{Experiment VII}

Effect of 6-Mercaptopurine on the Response to Antigens of Bone Marrow Cells of Normal Rabbits and of Lymph Node and Spleen Cells of Previously Immunized Rabbits.-

Normal rabbit bone marrow cells were collected and cultured in the presence of a well documented immunosuppressant, 6-mercaptopurine (6-MP) and/or with protein antigens for 5 days in vitro.

The lymph node and spleen cells were obtained from rabbits previously immunized with HSA and cultured in vitro in the same way as the bone marrow cells. The response of these cell suspensions to antigen was determined by the uptake of tritiated thymidine.

TABLE XI

Detection of Specific Antibody (Anti-HSA) in Antigen (HSA)-Stimulated Normal Rabbit Bone Marrow Cells by the Fluorescent Antibody Technique

\begin{tabular}{l|c}
\hline $\begin{array}{c}\text { Fluorescein isothiocyanate (FITC) conjugated protein } \\
\text { incubated with bone marrow smears }\end{array}$ & Detection of fuorescence \\
\hline HSA-FITC & ++ to +++ \\
BGG-FITC & No fluorescence \\
KLH-FITC & No fluorescence \\
Anti-HSA-FITC & No fluorescence \\
Anti-BGG-FITC & No fluorescence \\
HSA, followed by Anti-HSA-FITC & ++++ \\
HSA, followed by Anti-BGG-FITC & No fluorescence \\
HSA, followed by HSA-FITC & No fluorescence \\
\hline
\end{tabular}

As can be seen in Table XII, neither $100 \mu \mathrm{g}$ nor $1000 \mu \mathrm{g}$ of 6-MP had any detectable inhibitory effect on the basal uptake of tritiated thymidine by either the normal bone marrow cells or the lymph node and spleen cells obtained from previously immunized rabbits cultured in the absence of any antigen. A marked suppression of incorporation of tritiated thymidine, in comparison to control cultures, was observed when the normal rabbit bone marrow cells and lymphoid cells from the previously immunized rabbit were incubated with antigen and 6-MP.

\section{Experiment VIII}

Responsiveness to Antigens of the Lymphocyte-Rich Fraction of Normal Rabbit Bone Marrow Cells.-

Bone marrow cells obtained from normal rabbits were fractionated by centrifugation in a linear sucrose density gradient, prepared as described in Methods and Materials. Two fractions were collected, fractions I and II, and their response to antigens in vitro was compared to that of the whole bone marrow.

As has been described in a previous communication (21), fraction I consisted largely of lymphoid cells of various sizes as well as late erythroblasts, mature 
granulocytes, and some blast-like cells. Many mature erythrocytes were also present. Fraction III was composed mainly of mature granulocytes, granulocyte precursors, erythroblasts, undifferentiated blast-like cells, and a few monocytes and macrophages. Few mature lymphocytes were seen.

TABLE XII

Effect of 6-Mercaptopurine (6-MP) on the Response to Antigen(s) of Organ Cell Suspensions Obtained from Hyperimmunized and Normal Rabbits

\begin{tabular}{|c|c|c|c|c|c|c|c|c|c|c|}
\hline \multirow[b]{2}{*}{$\begin{array}{c}\text { Immune } \\
\text { state of donor } \\
\text { rabbit }\end{array}$} & \multirow[b]{2}{*}{$\begin{array}{c}\text { Cells of organ } \\
\text { tested }\end{array}$} & \multicolumn{9}{|c|}{$\begin{array}{c}\text { Incorporation of radioactive thymidine by cell suspensions incubated } \\
\text { with the following for } 5 \text { days }\end{array}$} \\
\hline & & Control & $\begin{array}{c}6 \mathrm{MP} \\
\underset{\mu \mathrm{g})}{(1000}\end{array}$ & $\begin{array}{l}6 \mathrm{MP} \\
(100 \\
\mu \mathrm{g})\end{array}$ & HSA & $\begin{array}{c}\mathrm{HSA}+ \\
6 \mathrm{MP} \\
(1000 \\
\mu \mathrm{g})\end{array}$ & $\begin{array}{c}\text { HSA }+ \\
6 \mathrm{MP} \\
(100 \\
\mu \mathrm{g})\end{array}$ & KLH & $\begin{array}{l}\text { KLH }+ \\
6 \mathrm{MP} \\
(1000 \\
\mu \mathrm{g})\end{array}$ & $\begin{array}{c}\text { KLH }+ \\
6 \mathrm{MP} \\
(100 \\
\mu \mathrm{g})\end{array}$ \\
\hline & & $c p m^{*}$ & $c p m$ & $c p m$ & $c p m$ & $c p m$ & $c p m$ & $c p m$ & $c p m$ & $c p m$ \\
\hline $\begin{array}{l}\text { Hyperimmunized } \\
\text { (HSA) }\end{array}$ & Lymph node & 5,390 & 5,720 & 5,853 & 18,218 & 3,520 & 7,923 & ND $\ddagger$ & $\mathrm{ND}$ & ND \\
\hline $\begin{array}{l}\text { Hyperimmunized } \\
\text { (HSA) }\end{array}$ & Spleen & 9,657 & 8,738 & 10,270 & 23,702 & 8,360 & 10,762 & ND & ND & ND \\
\hline $\begin{array}{l}\text { Normal nonim- } \\
\text { mune }\end{array}$ & Bone marrow & 10,005 & 10,076 & 10,801 & ND & ND & ND & 37,463 & 14,344 & 22,415 \\
\hline
\end{tabular}

Each value represents the mean of triplicate determinations.

$\ddagger N D$, not done.

TABLE XIII

The Response of Whole Normal Rabbit Bone Marrow and Bone Marrow Fractions to Protein Antigens Incubated In Vitro for 5 Days

\begin{tabular}{|c|c|c|c|c|c|c|c|c|c|}
\hline \multirow{3}{*}{ Antigen added } & \multicolumn{9}{|c|}{ Uptake of tritiated thymidine by the cell suspensions } \\
\hline & \multicolumn{3}{|c|}{ Whole bone marrow } & \multicolumn{3}{|c|}{ Fraction I } & \multicolumn{3}{|c|}{ Fraction II } \\
\hline & A & $\mathbf{B}$ & $\mathrm{C}$ & $\mathbf{A}$ & $\mathbf{B}$ & $\mathrm{C}$ & $\mathbf{A}$ & B & $\mathrm{C}$ \\
\hline$m g$ & $\mathrm{cpm}^{*}$ & $c p m$ & $c p m$ & $\mathrm{cpm}$ & $c p m$ & cpm & $c p m$ & cpm & $c p m$ \\
\hline Control-no antigen & 3,555 & 6,451 & 4,620 & 1,000 & 241 & 550 & 2,000 & 3,400 & 2,800 \\
\hline HSA -25 & 9,285 & 12,490 & 12,050 & 11,890 & 10,480 & 10,800 & 4,205 & 5,224 & 4,037 \\
\hline KLH -1 & 12,650 & 18,755 & 515,650 & 20,605 & 23,060 & 18,420 & 3,666 & 8,575 & 4,600 \\
\hline
\end{tabular}

* Each value represents the mean of triplicate determinations.

As can be seen in Table XIII, after 5 days of incubation with antigen, the uptake of tritiated thymidine by the whole bone marrow was 3-4 times that obtained in the absence of antigen (HSA and KLH). The uptake of tritiated thymidine by fraction I cells in the presence of antigen exceeded that of the whole bone marrow, whereas the incorporation of thymidine by the cells in fraction II was less than that of whole bone marrow. If the results are expressed in terms of specific thymidine incorporation, the values are 3-4 for whole bone marrow, 10-20 for fraction I, and 1.5-2.5 for fraction II. 
Whole bone marrow cell suspensions incubated for $3 \mathrm{hr}$ in $15 \%$ sucrose incorporated radioactive thymidine to the same degree as bone marrow cells not exposed to sucrose prior to incubation wtih the antigen in sucrose-free medium for 5 days.

\section{DISCUSSION}

This investigation is concerned with the events which transpire during the latent period of the primary immune response and with the role which the different lymphoid cells may play in the realization of cellular reactions culminating in antibody formation. The primary technique utilized was the in vitro blastogenic reaction in cell culture. The immunologic nature and mechanism of the blastogenic reaction by lymphocytes in vitro has been well documented in a number of review articles (24-27). On the basis of experimental results obtained to date, one may assume that, in the absence of a nonspecific mitogen, such as phytohemagglutinin, pokeweed, or streptolysin-S (24-27), the reaction is an immunologically specific one in that it can only be induced by specific antigen (24-33) or by homologous or genetically-dissimilar isologous lymphocytes (34-38). It cannot be induced by the incubation of lymphocytes from genetically identical, monozygotic twins, (38-40), nor by the incubation of lymphocytes from genetically dissimilar donors where one of the donors was made tolerant to the cells of the other donor or had been thymectomized at birth (37).

The cell culture technique was utilized along with the fragment culture method in the initial experiments in order to establish, in our hands, the immune nature of the blastogenic reaction obtained with the cell cultures. It was observed that only spleen and lymph node cells prepared from the organs of rabbits immunized 5-7 months previously and cultured in the presence of the antigen were stimulated to undergo blastogenesis and mitosis and to incorporate radioactive thymidine to a degree 10-20 times that obtained with control preparations. Although a good correlation was observed between the blastogenic response of immune rabbit lymph node cells and antibody formation by fragments of the same lymph nodes (Table IV), no such relationship was observed between immune spleen cells and spleen fragments. The spleen fragments of immunized rabbits produced very little or no antibody when cultured in vitro, probably owing to the fact that the rabbits had been immunized mainly via the foot pad administration of the antigen. However, immune spleen cells incorporated tritiated thymidine to a degree equal to or even greater than that of the immune lymph node cells. These results suggest that the blastogenic response is a measure of the immune status of the organ but need not be directly related to its capacity to synthesize humoral antibody. It has been demonstrated that a clear cut distinction cannot be made between cellular and humoral immunity on the basis of the in vitro blastogenic response. Mills (41) and Oppenheim et al. (42) observed that the lymphocytes from 
guinea pigs displaying only delayed hypersensitivity to tuberculin underwent transformation upon exposure to the specific antigen in culture whereas lymph node cells of animals which synthesized large quantities of humoral antibody failed to show transformation. On the other hand, Dutton and Eady (43), and Vischer and Stastny (44) observed that lymphoid cells of previously immunized animals reinjected to give a secondary antibody response responded with thymidine uptake in vitro at about the same time that antibody could be detected in the circulation. Loewi et al. (45) obtained incorporation of tritiated thymidine by lymphocytes of guinea pigs irrespective of whether they had been immunized with the antigen in Freund's adjuvant to induce strong delayed hypersensitivity (cellular immunity) or intravenously, to induce a pure humoral response. These results strongly imply that the blast cell transformation reaction measures both cellular and humoral immunity which might be anticipated since both of these activities are manifestations of lymphocyte activity.

On the other hand, it was observed that the bone marrow cells obtained from a previously immunized rabbit, unlike the lymph node and spleen cells from the same animal, failed to respond with blastogenesis and thymidine incorporation in vitro upon exposure to the specific immunizing antigen, but did respond markedly to other antigens to which the rabbit had not been previously exposed. Chapman et al. (46) have also reported the failure of bone marrow cells of immunized rabbits ("immune" bone marrow) to respond to the specific antigen in vitro. In fact, they reported that the immune bone marrow cell response was somewhat inhibited, relative to controls, by the specific antigen. They did not, however, test the reactivity of the bone marrow cells with respect to other, non-cross-reacting antigens in vitro.

Further investigations were carried out with cells of normal, uninjected rabbits. Normal bone marrow cells were observed to undergo blastogenesis and mitosis when incubated with a large variety of protein antigens, a bacterial antigen, and sheep red blood cells, although the magnitude of the response was somewhat different with respect to the different antigens. None of the cell cultures, prepared from the other lymphoid organs of the normal rabbitspleen, lymph node, thymus, sacculus rotundus, and appendix, reacted to any of the antigens in vitro. Although the basal activity of the various cell popuIations was high, as represented by the incorporation of tritiated thymidine in the control tubes, the specific tritium incorporation-that is, the ratio of tritium incorporated by the cells in the presence of the antigen to that incorporated in the absence of the antigen-was 3-10 for normal bone marrow cells, whereas it was approximately 1 for normal lymph node, spleen, and thymus cells. It should be noted that, as might be anticipated, the bone marrow cells failed to respond upon exposure to commercially available "isologous" rabbit serum albumin (RSA). This finding, coupled with the failure of bone marrow 
cells from previously immunized rabbits to respond to the specific antigens in vitro, precludes attributing the response of normal rabbit bone marrow cells to a mitogenically active chemical contaminant in the various antigen preparations. The high concentration of antigen required to induce the normal bone marrow blastogenic response upon initial exposure to antigen $(10-25 \mathrm{mg})$, compared to that required to initiate the response in lymph node and spleen cells of previously immunized rabbits $(1 \mathrm{mg})$, may be favorably compared to the much larger amount of antigen required to initiate a primary, as compared to a secondary, immune response in vivo (47). Evidence in favour of the specific nature of the bone marrow response emerged from the experiments in which rabbits were injected with a protein antigen (HSA or BGG or $\mathrm{KLH}$ ), sacrificed at various times thereafter, and had their bone marrow cells cultured in the presence of the antigen which had been injected in vivo as well as with other non-cross-reacting antigens. In each case, within $1 \mathrm{hr}$ to several days following antigen injection, the bone marrow cells lost their capacity to respond to the antigen with which the marrow donor animal had been injected whereas the cells' response to the other, non-cross-reacting antigens was marked and uniform. The specific failure of the bone marrow cells to respond to the immunizing antigen in vitro was still manifest even after 5-7 months. The specificity of the bone marrow response was further documented by the fact that bone marrow cells from tolerant rabbits did not respond to the tolerance-inducing antigen, whereas they did to the other antigens. That a true state of immunologic tolerance was achieved in the rabbits is indicated by the fact that they did not respond with antibody formation following reinjection of the antigen at $10 \mathrm{wk}$ of age, whereas control littermates responded vigorously. All the rabbits formed antibodies when injected with a non-cross-reacting antigen. Furthermore, the lymph node and spleen fragments of the tolerant animals, unlike those of immune animals, did not respond in culture upon exposure to the specific antigen. The immunologic nature of the bone marrow blastogenic response was demonstrated by the extent to which the blastogenic reaction could be inhibited by 6-mercaptopurine (6-MP), a known inhibitor of antibody formation in vivo and which was also shown to inhibit the antibody response of immune lymph node fragments in vitro and by the detection of antibody within the stimulated cells, using the fluorescent antibody technique.

Attempts were then initiated to identify the cell(s) in the bone marrow which is capable of undergoing transformation in the presence of the antigen in vitro. Normal rabbit bone marrow was separated into two fractions, $I$ and II, by centrifugation in a linear sucrose density gradient. Fraction I responded well upon exposure to various antigens whereas fraction II responded very poorly. The results of these experiments have been discussed at length elsewhere (21) and they strongly suggest that the responsive cells form a part of the lymphoid population of the bone marrow rather than some of the other 
cell types. These results imply that the normal bone marrow response to antigen in vitro is an immune response or the initial cellular event leading up to immunocyte differentiation and maturation and antibody formation in the primary response.

A finding which needs to be elaborated upon is the loss of reactivity of the bone marrow cells to the antigen in vitro within a few hours to a few days following administration of the antigen in vivo. This loss of reactivity is specific, since the marrow cells were still able to respond optimally to the other noncross-reactive antigens, and is long lasting. A definite relationship was found to exist between the quantity of the antigen injected into the rabbit and the time requirea for the bone marrow cells to lose their reactivity to the specific antigen in vitro. The bone marrow reactivity to antigen was lost irrespective of the mode of injection of the antigen. The "latent period," that is, the period of time which elapsed between the administration of the antigen and the loss of reactivity of the bone marrow to this antigen, lengthened as the amount of antigen injected decreased. Furthermore, the bone marrow did not lose responsiveness when the donor animal was injected with a "subantigenic" dose of the antigen (i.e., $100 \mu \mathrm{g}$ of HSA). In retrospect, such a result would be anticipated since the rate of migration of potentially immunocompetent cells out of the marrow would be dependent upon the rate of entry of antigen molecules into the marrow which, in turn, would be a function of the quantity of antigen injected. These findings suggest that potentially immunocompetent cells are released from the bone marrow following initial exposure to the antigen and that the bone marrow as a whole then becomes immunologically tolerant with respect to this specific antigen. This tolerance, if not permanent, has been found to persist for at least 7 months following the intravenous administration of the antigen. This interpretation of our results would also permit for an inexhaustible supply of potentially immunocompetent cells in the bone marrow, since only a small number would actually be released in response to a single antigen to proliferate in and populate the thymus and the peripheral lymphoid tissue. The cells lost from the bone marrow could be easily replaced by division of other primitive, uncommitted cells. The results also imply that the clonal selection theory of Burnet may indeed be operative, at least insofar as the bone marrow is concerned, since the loss of reactivity of the bone marrow to an antigen is specific to that injected antigen.

There can be little doubt, when examining the literature concerned with the cell source of antibody formation, of which the references cited represent only a very small sampling $(1-9,14,15,48-52)$, that the emphasis has been on the role of the lymphocyte in the immune response. Certainly, in the face of overwhelming evidence, one cannot doubt that the lymphocyte plays a major role in conferring immunity, both cellular and humoral. Although the role of the thymus in immunity has captivated a large number of investigators as well $(10,11,53-55)$, the bone marrow has received relatively scant attention. Un- 
doubtedly, the complex nature and heterogeneity of the cells comprising the bone marrow has deterred many investigators.

It has been known for a number of years that the injection of isologous or even homologous bone marrow cells into lethally $\mathrm{X}$-irradiated animals can prevent death and many of the symptoms or radiation illness (56-61). A relationship between marrow and thymus cells was demonstrated by Harris and Ford (62) who showed that at least some bone marrow cells migrate through the thymus. Micklem et al. (63) observed that the bone marrow, spleen, and thymus of irradiated mice were all recolonized predominantly or exclusively by descendants of injected isogeneic bone marrow cells.

Claman et al. $(64,65)$ injected irradiated mice with syngeneic thymus and/or spleen and/or marrow cells. Normal spleen cells produced some discrete areas of antibody production in recipient spleens, whereas mice receiving both marrow and thymus cells produced more centers of hemolytic activity in their spleens than mice receiving cells of either type alone, whether from normal or immune isogeneic animals. These authors suggested that one cell population contains cells capable of making antibody ("effector cells") but only in the presence of the other cell population ("auxiliary cells"). The data presented did not establish which cell suspension, thymus or bone marrow, contains either effector or auxiliary cells or how the cells interact. Miller and Mitchell (66) presented further evidence in favor of a bone marrow-thymus relationship in the induction of antibody formation. They injected thymus cells and sheep red cells into X-irradiated, syngeneic mice (primary host). $1 \mathrm{wk}$ later, the primary host was sacrificed and the spleen cells transferred to an $\mathrm{X}$-irradiated syngeneic mouse (secondary host), which also received sheep red cells and syngeneic bone marrow cells obtained from a normal donor. The secondary hosts were sacrificed at intervals of time and the spleen cells were assayed for hemolysin formation to sheep red cells by the Jerne plaque technique (67). A significant hemolysin-forming cell response was obtained only if the primary host had been injected with syngeneic thymus cells and sheep red cells. No significant response occurred if bone marrow cells were not given to the second irradiated host, if the first host had been given bone marrow cells instead of thymus cells, or if the primary host had been given horse erythrocytes rather than sheep red cells (68). These findings suggested that thymus cells had to first react with antigen before interaction with bone marrow cells could produce a significant response. Mitchell and Miller (68) also injected syngeneic or allogeneic thymus cells or thoracic duct cells into neonatally thymectomized mice inoculated with sheep erythrocytes, with a resultant increase in the number of hemolysin-forming cells in the spleens of these animals, and identified the hemolysin-forming cell as originating in the thymectomized host mice and not from the thoracic duct or thymus cells which had been administered.

A number of other experimental findings suggest a specific interaction be- 
tween thymus lymphocytes and antigen(s). Davies et al. $(69,70)$ have observed that thymus graft-derived cells can respond briskly to sheep red cells with a burst of mitotic activity. However, neither Davies et al. (69) nor Mitchell and Miller (68) could detect any antibody-forming cells following this interaction between the thymus cells and antigen. Davies et al. (69) transferred spleen cells, containing chromosomally marked thymus- and bone marrowderived cells, from a host mouse which had been immunized with sheep red cells, into an irradiated secondary host mouse. This latter host had been rendered isoimmune prior to irradiation so as to kill or prevent the proliferation of cells derived from either the bone marrow or thymus graft. They found that although "immune" thymus-derived cells were mitotically-reactive to antigenic stimulation in vivo, no antibody could be detected in the animals made isoimmune to the bone marrow-derived cells. On the other hand, recipients made isoimmune to the thymus-derived cells possessed considerable quantities of circulating antibody, and their spleens gave rise to large numbers of plaque-forming cells, suggesting that the thymus-derived cells are not capable of antibody formation nor of giving rise to antibody-forming cells and that the antibody-forming cell is marrow derived.

On the basis of the results obtained in the present study, it appears that the immediate precursor of the antibody-forming cell is derived from the bone marrow. It would also appear that the "immediate precursor of the $19 \mathrm{~S}$ hemolysin-forming cell" of Mitchell and Miller (68), the "effector cell" of Claman et al. $(64,65)$, the " $\mathrm{X}$ " cell of Sercarz and associates (71-73) and the " $\mathrm{PC}_{1}$ " cell of Makinodan and Albright (8) all represent the same cell as that described by the present authors and that it is also derived from a bone marrow precursor.

It is anticipated that a more precise identification of the antigen-responsive cell(s) in the bone marrow will be achieved by further studies using the more highly purified lymphocyte fractions which may be obtained by differential density gradient centrifugation. Although it was demonstrated that stimulated bone marrow cells contain specific antibodies, it has not yet been determined whether these antibodies are identical with the humoral antibodies detected in a classical immune response initiated and sustained in vivo. Experiments are currently in progress to attempt to elucidate further the nature of the in vitro bone marrow lymphocyte response and to relate it to the two main distinguishable immune responses-the humoral and cellular immune responses.

SUMMARY

Cell suspensions of immune rabbit lymph nodes and spleen were capable of undergoing blastogenesis and mitosis and of incorporating tritiated thymidine when maintained in culture with the specific antigen in vitro. They did not respond to other, non-cross-reacting antigens. The blastogenic response ob- 
tained with immune lymph node cells could be correlated with the antibody synthesizing capacity of fragment cultures prepared from the same lymph nodes. Cell suspensions of immune bone marrow responded to non-crossreacting antigens only whereas cell suspensions of immune thymus, sacculus rotundus, and appendix did not respond when exposed to any of the antigens tested.

On the other hand, neither fragments nor cell suspensions prepared from lymph nodes, spleen, and thymus of normal, unimmunized rabbits responded with antibody formation and blastogenesis when exposed to any of the antigens. However, normal bone marrow cells responded with marked blastogenesis and tritiated thymidine uptake. The specificity of this in vitro bone marrow response was demonstrated by the fact that the injection of a protein antigen in vivo resulted in the loss of reactivity by the marrow cell to that particular antigen but not to the other, non-cross-reacting antigens. Furthermore, bone marrow cells of tolerant rabbits failed to respond to the specific antigen in vitro. It was also demonstrated that normal bone marrow cells incubated with antigen are capable of forming antibody which could be detected by the fluorescent antibody technique. This response of the bone marrow cells has been localized to the lymphocyte-rich fraction of the bone marrow.

It is concluded that the bone marrow lymphocyte, by virtue of its capacity to react with blastogenesis and mitosis and with antibody formation upon initial exposure to the antigen, a capacity not possessed by lymphocytes of the other lymphoid organs, has a preeminent role in the sequence of cellular events culminating in antibody formation.

The authors wish to thank Dr. Bram Rose, Director, Division of Immunochemistry and Allergy, Royal Victoria Hospital, for his support of this project and his assistance in the preparation of this manuscript, and Miss Brenda Drechsler for her skilled assistance in carrying out many of the procedures.

\section{BIBLIOGRAPHY}

1. Stavitsky, A. B. 1961. In vitro studies of the antibody response. Advan. Immunol. $1: 211$.

2. Nossal, G. J. V. 1966. Antibody production in tissue culture. In Cells and Tissues in Culture. Willmer, editor. Academic Press, 3:317.

3. Dutton, R. W. 1966. In vitro studies of immunological responses of lymphoid cells. Advan. Immunol. 6:253.

4. Wilson, D. B., and R. E. Billingham. 1967. Lymphocytes and transplantation immunity. Advan. Immunol. 7:189.

5. Nossal, G. J. V. 1967. Mechanisms of antibody production. Ann. Rev. Med. 18:81.

6. Stone, S. H. 1967. Cellular commitments to immune responses. Ann. Rev. Microbiol. 21:181. 
7. Growans, J. L., and D. D. McGregor. 1965. The immunological activities of lymphocytes. Progr. Allergy. 9:1.

8. Makinodan, T., and J. F. Albright. 1966. Proliferative and differentiative manifestations of cellular immune potential. Progr. Allergy. 10:1.

9. Cochrane, C. G., and J. F. Dixon. 1962. Antibody production by transferred cells. Advan. Immunol. 2:206.

10. Miller, J. F. A. P., A. H. E. Marshall, and R. G. White. 1962. The immunological significance of the thymus. Advan. Immunol. 2:111.

11. Cooper, M. D., A. E. Gabrielson, and R. A. Good. 1967. Role of the thymus and other central lymphoid tissues in immunological disease. Anm. Rev. Med. 18:113.

12. Richter, M., A. Juhasz, B. Drechsler, and J. Myers. 1966. Synthesis of antibody in vitro by lymph node fragments using absorbable gelatin sponges. Nature. 210:645.

13. Boyden, S. V. 1951. The absorption of proteins on erythrocytes treated with tannic acid and subsequent hemagglutination by anti-protein sera. $J$. Exptl. Med. 93:107.

14. Juhasz, A., and B. Rose. 1965. The secondary antibody response in tissue culture. I. Observations on prolonged antibody synthesis by lymph node fragments in media of different composition. Canad. J. Biochem. 43:787.

15. Juhasz, A., and M. Richter. 1965. The secondary antibody response in tissue culture. II. Differences in the course of antibody synthesis to diphtheria toxoid and rat serum allumin. Canad. J. Biochem. 43:803.

16. Richter, M., and C. K. Naspitz. 1967. The variation in response of human peripheral lymphocytes to phytohemagglutinin in vitro. Intern. Arch. Allergy Appl. Immunol. 32:288.

17. Bain, B., and L. Lowenstin. 1965. Effect of technical variations on the mixed leukocyte reaction. Series Haematol. II. Histocompatibility Testing. Munksgaard, Copenhagen. 11:217.

18. Kopriwa, B. M., and C. P. Leblond. 1962. Improvements in the coating technique of radioautography. $J$. Histochem. Cytochem. 10:269.

19. Clark, H. F., and C. C. Shepard. 1963. A dialysis technique for preparing fluorescent antibody. Virology. 20:629.

20. Singhal, S. K., and M. Richter. 1968. Cells involved in the immune response. I. The response of normal rabbit bone marrow cells to the antigens in vitro. Intern. Arch. Allergy Appl. Immunol. 33:493.

21. Singhal, S. K., M. Richter, and D. G. Osmond. 1968. Cells involved in the immune response. III. Responsiveness to antigens of a lymphocyte-rich fraction of normal rabbit bone marrow. Intern. Arch. Allergy Appl. Immunol. In Press.

22. Osmond, D. G. 1967. The separation of lymphocytes from bone marrow by centrifugation in a density gradient. Anat. Record. 157:295.

23. Osmond, D. G. 1967. Separation of lymphocytes from bone marrow by centrifugation in density gradients and by filtration through glass bead columns. Expertl. Haematol. 14:37.

24. Robbins, J. H. 1964. Tissue culture studies of the human lymphocyte. Science 146:1648. 
25. Robbins, J. H. 1964. Human peripheral blood in tissue culture and the action of phytohemagglutinin. Experientia. XX:1.

26. Naspitz, C. K., and M. Richter. 1968. The action of phytohemagglutinin in vivo and in vitro. A review. Progr. Allergy. In Press.

27. Bach, F. H., and K. Hirschhorn. 1965. The in vitro immune response of peripheral blood lymphocytes. Seminars Haematol. 2:68.

28. Richter, M., and C. K. Naspitz. 1968. The in vitro blastogenic response of lymphocytes of ragweed sensitive individuals. J. Allergy. 41:140.

29. Zeitz, S. J., P. P. Van Arsdel, and D. K. McClure. 1966. Specific response of human lymphocytes to pollen antigen in tissue culture. $J$. Allergy. 38:321.

30. Girard, J. P., N. R. Rose, M. L. Kunz, S. Kobayashi, and C. E. Arbesman. 1967. In vitro lymphocyte transformation in atopic patients; induced by antigens. $J$. Allergy. 39:65.

31. Cowling, D. C., and D. Quaglino. 1965. Effect of some antigens on leucocyte cultures. J. Path. Bacl. 89:63.

32. Coulson, A. S., and D. G. Chalmers. 1967. Response of human blood lymphocytes to tuberculin PPD in tissue culture. Immunology. 12:417.

33. Hirschhorn, K., F. Bach, R. L. Kolodney, I. C. Firschein, and N. Hashem. 1963. Immune response and mitosis of human peripheral blood lymphocytes in vitro. Science. 142:1185.

34. Chalmers, D. G., A. S. Carlson, C. Evans, and S. Yealand. 1966. Stimulated human peripheral blood lymphocytes in vitro. II. Mixed lymphocyte cultures with related and unrelated donors. Intern. Arch. Allergy Appl. Immunol. 30:177.

35. Bach, F., and K. Hirschhorn. 1964. Lymphocyte interaction: A potential histocompatibility test in vitro. Science. 143:813.

36. Oppenheim, J. J., J. Whong, and E. Frei. 1965. The effect of skin homograft rejection of recipient and donor mixed leukocyte cultures. J. Exptl. Med. 122:651.

37. Wilson, D. B. 1967. Quantitative studies on the mixed lymphocyte interaction in rats. II. Relationship of the proliferative response to the immunologic status of the donors. J. Exptl. Med. 126:655.

38. Wilson, D. B., 1967. Quantitative studies on the mixed lymphocyte interaction in rats. I. Conditions and parameters of response. J. Exptl. Med. 126:625.

39. Bain, B., and L. Lowenstein. 1964. The mixed leukocyte reaction. Science. 145:1315.

40. Bain, B., M. R. Vas, and L. Lowenstein. 1964. The development of large immature mononuclear cells in mixed leukocyte cultures. Blood. 23:108.

41. Mills, J. A. 1966. The immunologic significance of antigen-induced lymphocyte transformation in vitro. $J$. Immunol. 97:239.

42. Oppenheim, J. J., R. A. Wolstencroft, and P. G. H. Gell. 1967. Delayed hypersensitivity in the guinea pig to a protein-hapten conjugate and its relationship to in vitro transformation of lymph node, spleen, thymus and peripheral blood lymphocytes. Immunology. 12:89.

43. Dutton, R. W., and J. D. Eady. 1967. An in vitro system for the study of the mechanism of antigenic stimulation in the secondary response. Immunology. 7:40. 
44. Vischer, T. L., and P. Stastny. 1967. Time of appearance and distribution of cells capable of secondary immune response following primary immunization. Immunology. 12:675.

45. Loewi, G., A. Temple, and T. L. Vischer. 1968. The immunological significance in the guinea-pig of in vitro transformation of lymph node, spleen and peripheral blood lymphocytes. Immunology. 14:257.

46. Chapman, N. D., R. M. E. Parkhouse, and R. W. Dutton. 1964. Proliferation in lymphoid and myeloid tissues from immunized rabbits. Proc. Soc. Exptl. Biol. Med. 117:708.

47. Sterzl, J., and M. Jilek. 1967. Number of antibody-forming cells in primary and secondary reactions after administration of antigen. Nature. 216:1233.

48. O'Brien, T. F., M. C. Michaelides, and A. H. Coons. 1963. Studies on antibody production. VI. The course, sensitivity, and histology of the secondary response in vitro. $J$. Exptl. Med. 117:1053.

49. McGregor, D. D., P. J. McCullagh, and J. L. Gowans. 1967. The role of lymphocytes in antibody formation. I. Restoration of the haemolysin response in $\mathrm{X}$-irradiated rats with lymphocytes from normal and immunologically tolerant donors. Proc. Roy. Soc. London, Ser. B. 168:229.

50. Ford, W. L., and J. L. Gowans. 1967. The role of lymphocytes in antibody formation. II. The influence of lymphocyte migration on the initiation of antibody formation in the isolated, perfused spleen. Proc. Roy. Soc. London, Ser. B. 168:244.

51. Gowans, J. L., and J. W. Uhr. 1966. The carriage of immunological memory by small lymphocytes in the rat. J. Exptl. Med. 129:1017.

52. Gowans. J. L. 1962. The fate of parental strain small lymphocytes in $\mathrm{F}_{1}$ hybrid rats. Ann. N.Y. Acad. Sci. 99:432.

53. Experimented and clinical studies. In The Thymus. G. E. W. Wolstenholme, editor. Churchill, London. 1966.

54. The thymus in immunobiology. In Structure, Function and Role in Disease. R. A. Good, and A. E. Gabrielson, editors. Harper and Row. 1964.

55. Miller, J. F. A. P., and P. Osoba. 1967. Current concepts of the immunological function of the thymus. Physiol. Rev., 47:437.

56. Congdon, C. C. 1957. Experimental treatment of total-body irradiation injury: A brief report. Blood. 12:746.

57. Trentin, J. J. 1956. Effects of X-ray dose on mortality and skin transplantability in mice receiving $F_{1}$ hybrid marrow. Proc. Soc. Exptl. Biol. Med. 93:98.

58. Mannick, J. A., H. L. Lochte, C. A. Ashley, E. D. Thomas, and J. W. Ferrebee. 1960. Autografts of bone marrow in dogs after lethal total-body radiation. Blood. 15:255.

59. Morrison, J. H., and J. R. Toepfer. 1967. Survival of lethally X-irradiated rats after treatment with isogenic marrow lymphocytes. Am. J. Physiol. 213:923.

60. Congdon, C. C., and I. S. Urso. 1957. Homologous bone marrow in the treatments of radiation injury in mice. Am. J. Path. 33:745.

61. Gengozian, N., T. Makinodan, and I. C. Shekarchi. 1961. Transplantation of antibody-forming cells in lethally irradiated mice. J. Immunol. 86:113.

62. Harris, J. E., and E. E. Ford. 1964. Cellular traffic of the thymus: Experiments with chromosome markers. Nature. 201:884. 
63. Micklem, M. S., C. E. Ford, E. P. Evans, and J. Gray. 1966. Interrelationships of myeloid and lymphoid cells: Studies with chromosome marked cells transferred into lethally irradiated mice. Proc. Roy. Soc. London, Ser. B. 165:78.

64. Claman, H. N., E. A. Chaperon, and R. F. Triplett. 1966. Thymus-marrow cell combinations. Synergism in antibody production. Proc. Soc. Exptl. Biol. Med.122:1167.

65. Claman, H. N., E. A. Chaperon, and R. F. Triplett. 1966. Immune competence of transferred thymus-marrow cell combinations. J. Immunol. 97:828.

66. Miller, J. F. A. P., and G. F. Mitchell. 1967. The thymus and the precursors of antigen reactive cells. Nature. 216:659.

67. Jerne, N. K., and A. A. Nordin. 1963. Plaque formation in agar by single antibody-producing cells. Science. 140:405.

68. Mitchell, G. P., and J. F. A. P. Miller. 1968. Immunological activity of thymus and thoracic-duct lymphocytes.Proc. Natl. Acad. Sci. 59:296.

69. Davies, A. J. S., E. Leuchars, V. Wallis, R. Merchant, and E. V. Elliot. 1967. The failure of thymus-derived cells to produce antibody. Transplantation 6:222.

70. Davies, A. J. A., E. Leuchars, V. Wallis, and P. C. Koller. 1966. The mitotic response of thymus-derived cells to antigenic stimulus. Transplantation. 4:438.

71. Dowden, S. J., and E. E. Sercarz. 1967. The X-Y-Z scheme of immunocyte maturation. II. The effect of antigen on spontaneous escape from immune paralysis. J. Immunol. 98:827.

72. Sercarz, E. E., and V.S. Byers. 1967. The X-Y-Z scheme of immunocyte maturation. III. Early IgM memory and the nature of the memory cell. J. Immunol. 98:836.

73. Byers, V. S., and E. E. Sercarz. 1968. The X-Y-Z scheme of immunocyte maturation. IV. The exhaustion of memory cells. J. Exptl. Med. 127:307. 
FIG. 1. Radioautograph of lymph node cells of previously immunized (HSA) rabbit incubated with HSA for 5 days at $37^{\circ} \mathrm{C}$. $\times 630$.

FIG. 2. Radioautograph of unfractionated normal rabbit bone marrow obtained from a rabbit immunized with HSA and incubated with $\mathrm{KLH}$ for 5 days at $37^{\circ} \mathrm{C} . \times 630$. 

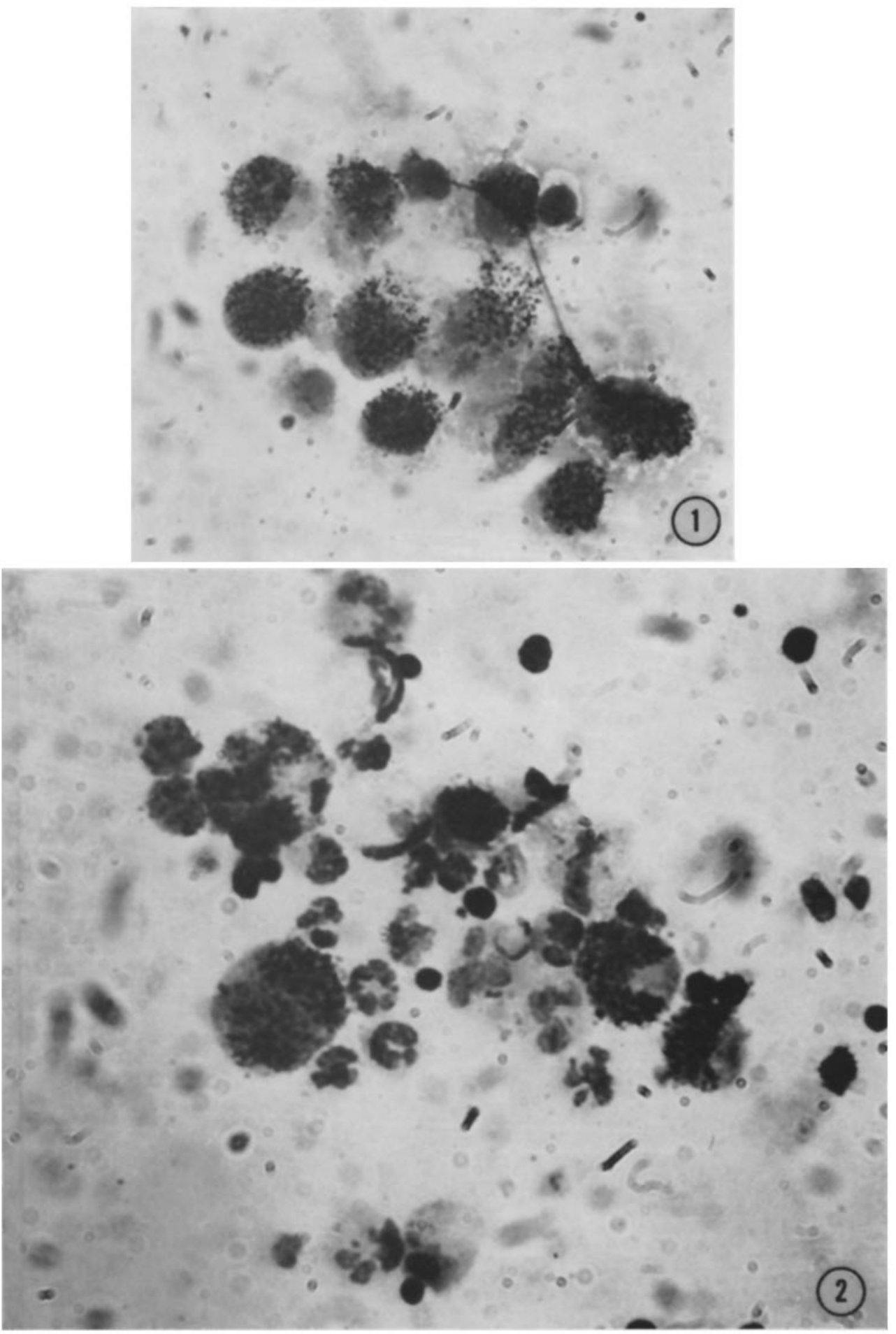

1127 


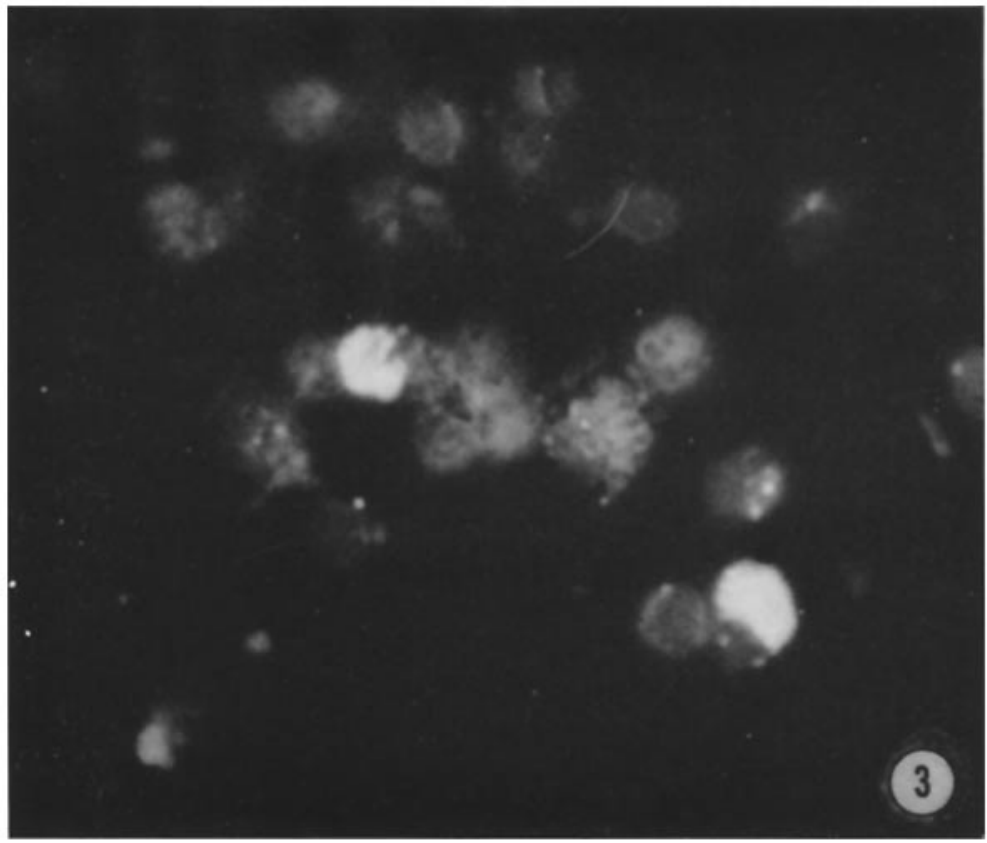

FIG. 3. Specific fluorescence observed subsequent to incubation of normal bone marrow cells with HSA for 5 days at $37^{\circ} \mathrm{C}$ and stained with HSA followed by antiHSA-FITC. $\times 630$. 